\title{
声帯ポリープを合併した喉頭顆粒細胞腫の一症例
}

\author{
佐々木 俊 - ${ }^{1)}$ ·福 田宏 之 ${ }^{2)}$ 坂 口良 平 ${ }^{3)}$
}

\section{A Case of Granular Cell Tumor of Larynx with Vocal Fold Polyp}

\author{
Shunichi Sasaki ${ }^{1)}$, Hiroyuki Fukuda ${ }^{2)}$ and Ryouhei Sakaguchi ${ }^{3)}$
}

Granular cell tumor arising in the larynx is very rare, especillay in Japan, where only 10 cases have been reported. A case of the said tumor, a 42 year old male that complained of hoarseness, was reported. The tumor formed on the posterior portion of the vocal fold with a complicating vocal fold polyp. Following removal of tumor with forceps, he underwent $\mathrm{CO}_{2}$ laser vaporization totally together with surrounding normal tissue of the vocal fold. Immunohistochemical examinations showed reactivity for S-100 protein, vimentin, and Leu 7. These results suggest that this tumor is derived from Schwann cell of the peripheral nerve. In general, this tumor grows slowly. His chief complaint was perhaps caused by vocal fold polyp. It is possible for vocal fold polyp to arise, because the existence of this tumor under the mucosa of the vocal fold gives some stimulation to the surface of the mucosa.

Key words：喉頭腫瘍, 顆粒細胞腫, 喉頭レーザー手術

\section{I.は じめに}

顆粒細胞腫は皮虑, 軟部組織をはじめ, 全身のほとんど の臓器に発生する比較的稀で, 時として多発例や悪性化例 の報告もあるが，その多くは良性の腫瘍である。耳鼻咽喉 科領域では, 舌縁および舌背の口腔などに発生し, 喉頭に 発生するのは極めて少なく, 本邦では著者らが検索しえた

表 1 本邦における喉頭顆粒細胞腫症例

\begin{tabular}{|c|c|c|c|c|c|}
\hline 報告者 & 性 & 年齢 & 主訴 & 部位 & 治療 \\
\hline 関 谷 & 男 & 43 & 嗄声 & 仮声带 & 喉頭微細手術 \\
\hline 山口 & 男 & 72 & 嗄声 & 声帯前 $1 / 3$ & 喉頭截開術 \\
\hline 末 永 & 女 & 56 & 嗄声 & 声帯後部 & 喉頭微細手術 \\
\hline 山 岨 & 女 & 50 & 咽頭異常感 & 披裂堠頭蓋七ダ咽頭面 & 咽頭側切開術 \\
\hline 川島 & 女 & 43 & 嗄声 & 仮声帯～披裂部 & 唉頭截開術 \\
\hline 森 & 女 & 47 & 嗄声 & 膜様部後部～披裂部 & 喉頭截開術 \\
\hline 都 築 & 男 & 51 & 嗄声 & 仮声帯 & 喉頭截開術 \\
\hline 熟 崎 & 男 & 47 & 咽喉頭異常感 & 膜様部やや後方 & 喉頭微細手術 \\
\hline 大 谷 & 男 & 42 & 嗄声 & 声帯突起 & 喉頭微細手術 \\
\hline 平 山 & 女 & 13 & 嗄声 & 声帯前 $1 / 3$ & $\begin{array}{l}\text { 喉頭微細手術 } \\
\text { 喉頭微細手術 }\end{array}$ \\
\hline 本症例 & 男 & 42 & 嗄声 & 声帯後方 & 喉頭微細手術 \\
\hline & & & & & レーザー手術 \\
\hline
\end{tabular}

1 ）足利赤十字病院耳鼻咽喉科

2 ) 慶應義塾大学医学部耳鼻咽喉科学教室

3 ) 清水市立病院耳鼻咽喉科

1 ) Department of Otorhinolaryngology, Ashikaga Red Cross Hospital

2 ) Department of Otorhinolaryngology, Keio University

3 ) Department of Otorhinolaryngology, Shimizu Municipal Hospital
限りでは，文献上10例を数えるにすぎない（表 1$)^{1 \sim 10)}$. 今回われわれは声帯ポリープを合併した喉頭顆粒細胞腫の 一症例を経験したので, 若干の文献的考察を加えて報告す る.
II. 症
例
症 例：42才, 男性
初 診：1995年 7 月19日
主 訴：嗄声

現病歴：1995年夏頃より嗄声を認め, 某耳鼻咽喉科を受 診し, 声帯ポリープを指摘されるもそのまま放置する。 1995年夏頃より症状が増強したため当科を受診した.

既往歴：特記すべきものなし
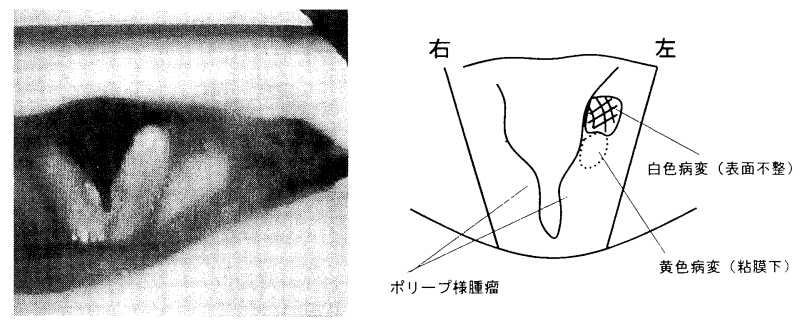

図 1 喉頭ファイバースコピー下所見 


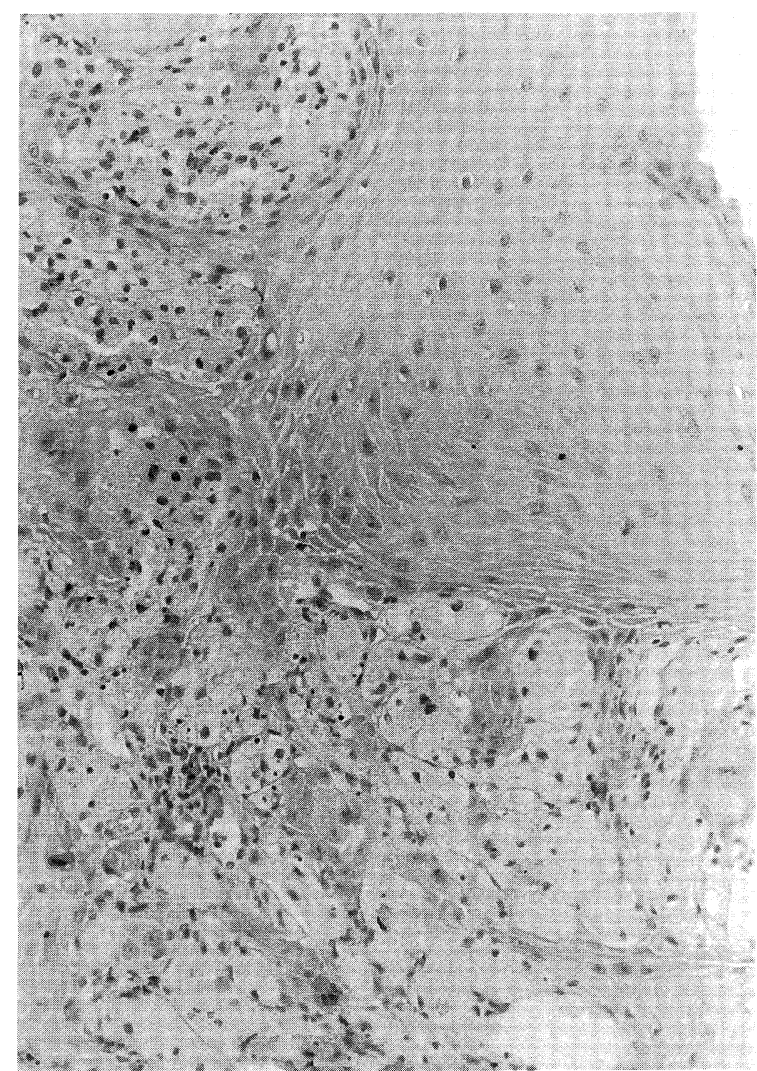

図 2 病理組織標本 $(\mathrm{HE}$ 染色, $\times 230)$ 反応性に増殖した上皮と大小の顆粒を含む腫瘍細胞

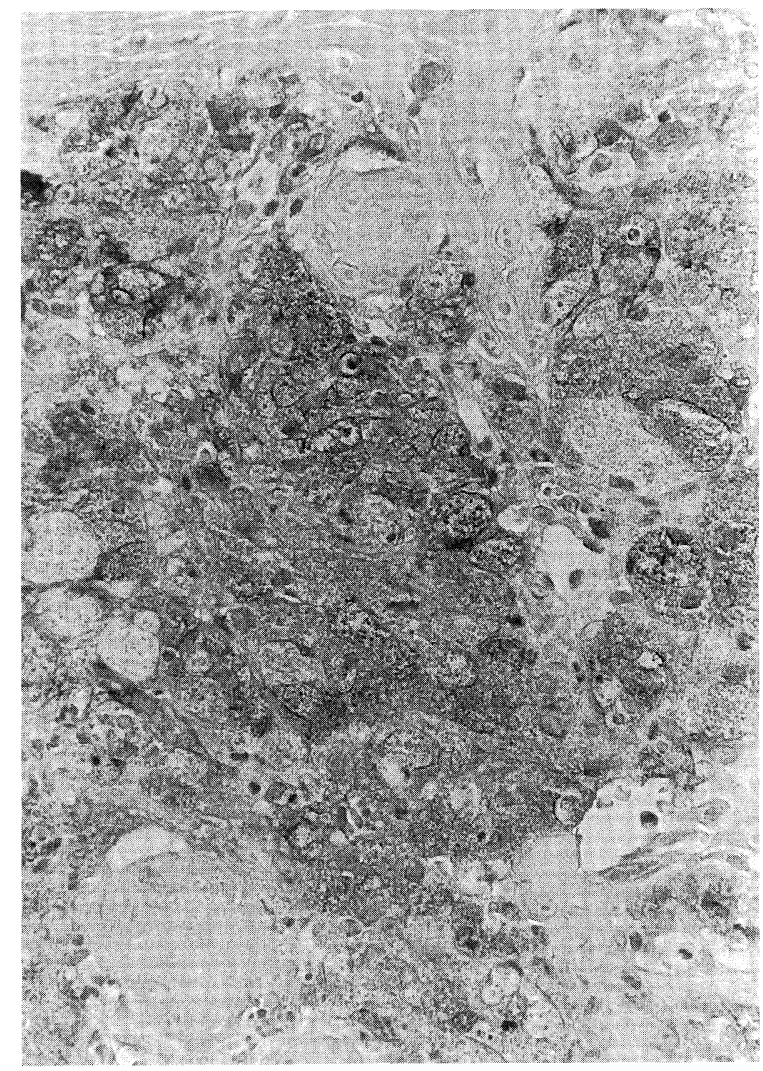

図 4 免疫組織化学的検查 $(S-100$ 蛋白, $\times 460)$ 抗 S-100蛋白に陽性

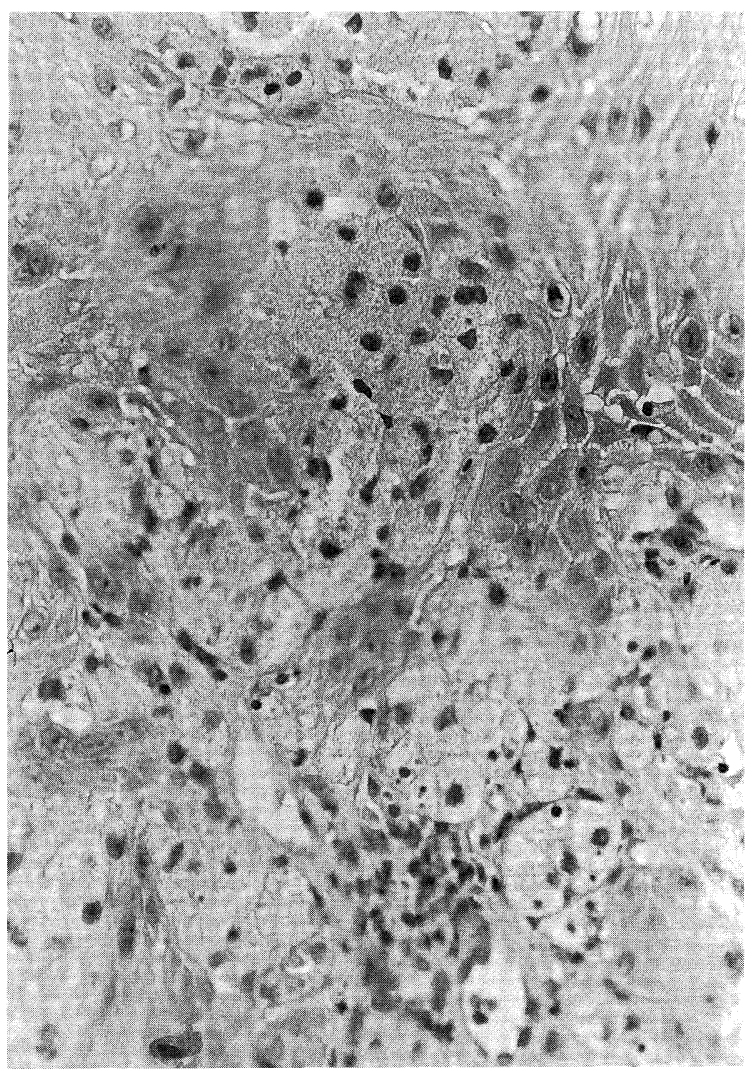

図 3 病理組織標本 $(\mathrm{HE}$ 染色, $\times 460)$ 好酸性顆粒細胞質を有する小型濃染核をもつ腫瘍細胞

家族歴：特記すべきものなし

嗜好歴：40本／1日，20年の喫煙歴がある。

初診時所見：喉頭ファイバースコピー下にて両側声帯膜 様部中央にポリープ様腫瘤を，さらに左声帯後方に表面が やや凹凸不整で白色を呈する腫瘤病変を認めた（図 1 ）. この白色病変は膜様部腫瘤とは明らかに異なり，ストロボ スコピー上粘膜波動は消失し，肉眼的には悪性腫瘍を思わ せた。頸部をはじめ, その他耳鼻咽喉科領域に異常を認め ず, 一般末梢血液検査, 血液生化学検査, 一般尿検査でも 異常を認めなかった.

臨床経過：1996年 8 月20日, 全身麻酔下にて喉頭微細手 術を施行した. 顕微鏡下での視診, 鉗子による触診にて,

膜様部腫瘤はポリープと診断し鉗除した. 左声帯後方に認 められる白色病変は表面は凹凸を認め, 鉗子にて非常に硬 く触知した，その白色病変と左声带ポリープとの間の粘膜 下に，囊胞を思わせる黄色病変を認め, 粘膜に切開を入れ ると, 硬く充実性で被膜を持たない腫瘤が粘膜下に後方の 白色病変と連なって存在しており，大きく腫瘤を鉗除した. 鉗除後の声带は柔らかく, 視診上は腫瘤病変の残存を認め なかった. 病理組織学的検査にて, 両側膜様部はポリープ, 左声帯後方は顆粒細胞腫の診断を得た. 摘出病変の切除断 端として提出した部位からも腫瘍細胞を認め, また声帯以 外に腫瘍の存在を思わせる部位がないことより, 同年 8 月 27日，再度全身麻酔下にて喉頭微細手術を施行した。挿管 
表 2 免疫組織学的所見

\begin{tabular}{lcc}
\hline \hline \multicolumn{1}{c}{ Antibody } & Sources & Reactivity \\
\hline S-100 protein* & Dako & + \\
Leu 7 & B-D & + \\
Keratin & Dako & - \\
EMA & Dako & - \\
CEA & Dako & - \\
Vimentin & Dako & ++ \\
Smooth muscle actin & Dako & - \\
KP-1 & Dako & - \\
\hline$* \quad ;$ polyclonal antibody & & \\
B-D ; Becton-Dickinson & & \\
+ ; almost all the tumor cell positive \\
$+\quad$; less than 25\% of the tumor cell positive
\end{tabular}

チューブを喉頭鏡で上方に挙上し，炭酸ガスレーザーにて 左声带後方を中心に広く蒸散させた. 蒸散後の病理組織学 的検査にて腫瘍の残存は認めず，現在術後経過観察中であ る.

\section{III. 病理組織学的所見}

病理組織学的検査にて, ヘマトキシリン・エオジン染色 で好酸性顆粒細胞質を有する小型濃染核を持つ細胞が索状 に配列しており，粘膜上皮が反応性に増殖している（図 2 , 図 3 ). 腫瘍細胞は抗 S-100蛋白抗体陽性であった（図 4 ）。 免疫組織学的検索の結果は表 2 にまとめた. 以上の結果よ りSchwann 細胞由来の喉頭顆粒細胞腫と考えられた.

\section{V. 考按}

顆粒細胞腫（granular cell tumor）は1926年にAbri-

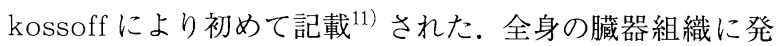
生し, 独特な組織像をもつ良性腫瘍である。顆粒細胞腫の 発生起源には, 横紋筋由来説 ${ }^{12)}$ 神経細胞由来説 ${ }^{13)}$, 組織球 由来説 ${ }^{14,15)}$, 線維芽細胞由来説 ${ }^{16)}$, さらには部位によって 種々の細胞より発生しうるという多起源説 ${ }^{17)}$ など, 以前 より様々な説が発表されてきているが, 現在では免疫組織 化学的検索にて Schwann 細胞由来説が有力となってい $~ る^{18)}$. 免疫組織学的検索において, 顆粒細胞腫における S100蛋白の局在はよく知られており, 本腫瘍のSchwann 細胞由来説の重要な根拠になっており ${ }^{19,20)}$, Schwann 細 胞由来説を支持する所見とみなすことができるであろう ${ }^{14)}$. さらに，髄鞘，oligoedendroglia， Schwann 細胞および それらから発生する腫瘍の検索手段として用いられている Leu $7^{21)}$ も陽性であったことから，本腫瘍はSchwann 細 胞由来であることが示唆された。

本腫瘍は皮膚および皮下組織に最も多く発生し，32.6\%， 次いで舌を含む口腔内約 $28 \%$, 以下乳房, 消化管, 気道, 虫垂, 下垂体が続く ${ }^{22)}$. 気道での発生は喉頭に最も多く, 欧米では約 $10 \%{ }^{23)}$ とされているが喉頭に発生する腫瘍と しては，かなり稀である. 1973年の関谷らの報告以降，本 邦における喉頭顆粒細胞腫は，我々が検索しえた限りでは
10例の報告を見るにすぎない。

好発年齢は, 30代から40代といわれ，本邦症例でも13才 より $72 才^{1 \sim 10)}$, 平均 46.4 才である.

発生部位は本症例のように声带後部が最も多く，次いで 披裂部，仮声帯に認められる ${ }^{1 \sim 10)}$.

症状は嗄声がほとんどで，咽喉頭異常感を訴える者もあ $る^{1 \sim 10)}$. 好発部位として声帯後方が多いのに, 嗄声を認め る例が多いのは，腫瘍が成長し，声門閉鎖不全を生じたた めと理解されているが, 本症例では腫瘍の大きさは比較的 小さく, 同時に存在していた声帯ポリープが嗄声の原因と も考えられる。

視診上の特徴として腫瘍の色調は白〜灰白色, ピンク〜 赤色が多く, 形状は polyp 様, polypoid 様, nodular 様 のものが多いといわれている5). 腫瘍が非常に固いことが 手術時の本腫瘍の特徴で，時には硬すぎて鉗除できない症 例も報告されている ${ }^{24)}$.

鑑別診断としては, 声帯ポリープ, 喉頭襄腫, 喉頭肉芽 腫, 喉頭アミロイドーシス, 良性腫瘍（線維腫，神経鞘腫， 軟骨腫, 脂肪腫など), 悪性腫瘍などである ${ }^{4)}$. 腫瘍を覆う 上皮に偽癌性増殖は顆粒細胞腫の半数から 3 分の 2 程度に 見られ ${ }^{25)}$, 喉頭ではその頻度が高い26) といわれており，生 検時に検体を大きく採らず上皮のみの採取では扁平上皮癌 との鑑別が困難となることもあり得る.

治療は腫瘍の大きさ，部位により，喉頭微細手術，また は喉頭截開術などが行われ摘出される. 本腫瘍は再発例 ${ }^{5}$ や悪性化 ${ }^{27)}$ の報告もあり，また適確な病理組織診断を得 るためにも早期の全摘出が適切な治療法といえる. しかし, 腫瘍自体が明らかな被膜を持たず，その境界が不明暸であ ることより, 完全摘出には周囲健常組織を含めた切除が必 要といわれている ${ }^{6)}$. 本症例には, 鉗子による腫瘍摘出后 に炭酸ガスレーザーを使用したが，もちろんレーザーによ る蒸散の範囲が悪性腫瘍治療時より狭くなっており, 術後 の音声は良好で喉頭ストロボスコピーにて粘膜波動も良好 である. 腫瘍の完全摘出, ならびに術後の音声を考慮して も, 本疾患に対し, 炭酸ガスレーザー手術は有効な治療法 の一つと考えられた.

本症例の 1 つの特徴は顆粒細胞腫に声帯ポリープを合併 したことである。一般に顆粒細胞腫の発育は緩徐といわれ ており ${ }^{4)}$ また発生部位が声帯後部に多く認められている ことより，本疾患による嗄声の主たる原因は，膜様部に発 生したポリープであるとも考えられる．たまたま同時に腫

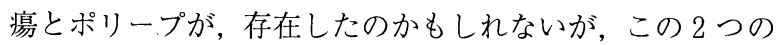
疾患の相互作用を考えると, 初めは声帯囊胞のように黄色 く見えた粘膜下の部分に腫瘍ができ，一方は声帯後方で粘 膜上に進展し, 他方では粘膜下の腫崵の発育がその上皮に 反応性増殖を起こさせて, 後に炎症性疾患としてポリープ を発生させた可能性もあるのではないかと推察された。

本疾患は術後約 1 年が経過し再発は認めてはいないが, 今後も長期間に渡る経過観察が必要であると思われる。 


\section{V. 結語}

1 ）42才，男性の声带ポリープを合併した喉頭顆粒細胞 腫の一例を経験したので, 文献的考察を加えて報告した.

2 ) 顆粒細胞腫の手術に際して，炭酸ガスレーザーが有 用であると思われた.

3 ) 顆粒細胞腫の存在が，なんらかの刺激を粘膜上皮に 与え, 声帯ポリープを合併したのではないかと推察された。

稿を終えるにあたり，御協力いただいた足利赤十字病院 検査部部長小島勝博士に感謝いたします.

本論文の要旨は第 8 回日本喉頭科学会（1996年 5 月, 旭 川市）においてロ演した。

\section{文献}

1) 関谷 透：喉頭 granular cell tumor. 日耳鼻 76 : 710,1973

2）山口宗彦ほか：Granular cell myoblastoma of larynx の 1 例. 耳鼻臨床 68：983〜986, 1975.

3）末永 通ほか：喉頭顆粒細胞腫の 1 例。日気食会報 $33: 384 \sim 388,1982$.

4）山岨達也ほか：披裂喉頭蓋ひだに発症した granular cell tumor の 1 症例. 耳喉 $58: 99 \sim 107,1986$.

5）川島 理ほか：喉頭の granular cell tumor の 1 例. 耳喉 $58: 423 \sim 428,1986$.

6) 森 敏裕ほか：喉頭顆粒細胞腫の 1 例. 耳喉頭頸 $62 ： 227 \sim 232,1990$.

7）都築 達ほか：喉頭顆粒細胞腫の 1 例. 日本喉頭科 学会抄録 $95: 95,1992$.

8）熟崎政治ほか：声帯に発生した顆粒細胞腫の一症例. 耳鼻臨床＼cjkstart補 $58 ： 55,1992$ 。

9）大谷尚志ほか：喉頭顆粒細胞腫の一症例. 日気食会 報 $45 ： 199 \sim 200,1994$

10）平山方俊ほか：小肾の喉頭顆粒細胞腫の 1 例. 日気 食会報 $46 ： 309 \sim 313,1995$.

11) Abrikossoff : Uber Muoma, ausgehend von der qergestreiften willkurlichen Muskulatur. Virchow Arch Path Anat 260: 215 233, 1926.

12) Gorlin RJ : Face, Lips, Tongue, Teeth, Oral Soft Tissue, Salivary Grands, and Neck, Anderson's Pathology 2 (Kissane, J.M., ed.), 1002 1054, The CV Mosby Comp., St. Louis, 1985.

13) Garanics JC et al: Granular cell myoblastoma. Cancer 25:542 550, 1970 .
14) Azzopardi JG : Histogenesis of granular cell "myoblastoma" JP Bact 7:85 94, 1956.

15) Pearse AGE: The histogenesis of granular cell myoblastoma (? granular cell perineural fibroblastoma). J Pathlo Bact 62 : 351 362, 1950.

16) Fust JA et al: On the neurogenesis of so-called granular cell myoblastoma. Am J Clin Pathol $19: 522 \sim 535,1949$.

17) Nishioka $\mathrm{H}$ et al : Immunohistochemical study of granular cell tumors of the neurohypophysis. Virchow Arch B Cell Pathol 60:413 417, 1991.

18）中里洋一ほか：Granular cell tumor の免疫組織化 学的多様性と組織発生について。病理と臨床 7: 99 105, 1989 .

19) Nakazato $Y$ et al : Immunohistochemical localization of S-100 protein in granular cell myoblastoma. Cancer 49: 1624 1628, 1982.

20) Mukai $\mathrm{M}$ : Immunohistochemical localization of S-100 protein and peripheral nerve myelin basic proteins ( $\mathrm{P}_{2}$ protein, $\mathrm{P}_{0}$ protein) in granular cell tumors. Am J Pathol 112: 139 146, 1983.

21) Perentes $E$ et al : Immunohistochemical recognition of human nerve sheath tumors by anti-Leu 7 monoclonal antibody. Acta Neuropathol (Berl.) $68: 319 \sim 324,1985$.

22) Peterson LT: Granular-cell tumor : Review of the literature and report of a case. Oral Surg $37: 728 \sim 735,1975$.

23) Kenefick C: Granular cell myoblastoma of the larynx. J Laryngol Otol $92: 521 \sim 523,1978$.

24) Booth JB et al: Granular cell myoblastoma of the larynx. Acta Otolaryng 70:279 293, 1970.

25) Batsakis JG et al: The pathology of head and neck tumors: fibroadepose tissue and skeletal muscle, part 8. Head Neck Surg 3:145 168, 1980.

26) Agarwal RK et al: Granular cell tumor of the larynx. Otolaryngol Head Neck Surg 87 : 807 814, 1979.

27） Busanny-Capsari von $\mathrm{W}$ et al：6）より引用

別刷請求先 $\bar{\top} 326$ 足利市本城3-2100 足利赤十字病院耳鼻咽喉科 佐々木俊一 